\title{
O-172 内シャント狭窄に対するPTA施行例の検討
}

\author{
川鼠病院1），小松島赤十字病院2） \\ 小林 博人1）、水口 潤1）、川兒 周1）、城野 良三2)
}

【い的】血液透析患者の長期生存に伴いブラッドアクセスを良好に維持することは、患者の長期予 後を方们する因子の1つになってきている。内シャント狭窄をきたした18人に対して、計26回血管温存 の性的に経皮的血管形成術（PTA）を施行した。【対象】当院にて血液透析を受けている患者にシャ ント血流イ心、静脈内川:上暈等のトラブルが生じた場合、内シャント造影を施行する。狭窄がみられ たものは18人で、PTAを施行したものは、再狭窄にて再拡張を要したもの及び、複数の狭窄部位に拡 啡をしたものをあわせて計26回であった。性別は、男性10名、女性8名、透析歴は1１7年、狭矣率は フィルム1:48－87\%であった。また、一部エコーにて、狭窄部位の血管壁の肥厚の程度を測定した。

【方法】透視卜に血管拡掁用バルーンカテーテル（Meadox Surgimed A / S 社製オルバートバルーン カテーテル）を插入し、狭窄部に扔いてバルーン内に造影剂を入れ膨らませた。バルーン内压は6ー10 父认、加1年間は3－5分間、透視下で狭窄部が十分に膨らむまでこの操作を3、4回繰り返した。【結 果】PTA施行後狭察率は $33.5 \pm 18.2 \%$ であり、施行前後比較して有意に改善していた。施行後3力月間 開份例は12例、6力月間開存例は6例、最長で14カ月問で現在も開存している。現在開存しているもの は9例、泩6.8カ月である。PTA中血管壁の損傷や血管の攣縮等により閉塞しシャント手術となったも のは4例であった。【考察】PTAは、患者への侵襲が少なく、繰り返し治療が行え、血管を温存すると いうことには份効であると考えられる。しかし長期搪張例が少ない、カテーテルが高価である、術前 に㧙非川能の程度及び、垃期開存の予測が困難である、などの問題も多い。今後症例の蓄積により長 期開存例の検封、術前の㹨窄部の評価を通してPTAの適応などについて検討が必要と思われる。

\section{O-173 犬界流短期保存モデルにおける SMA-SOD投与の模时}

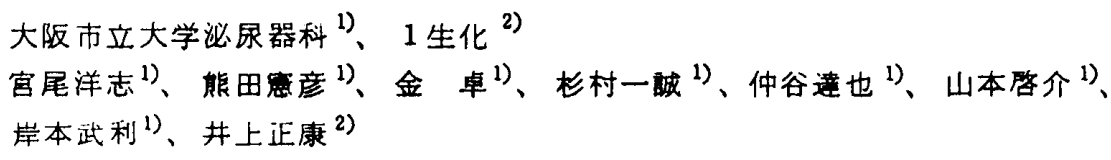

【目的】篧流短期保存モテルにおいてスチレンマレィン酸スーパーオキサイドティスムターセ

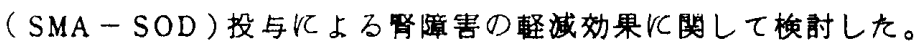

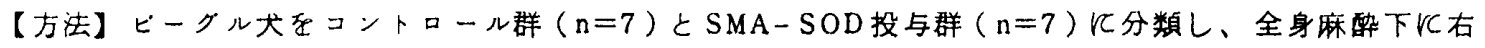

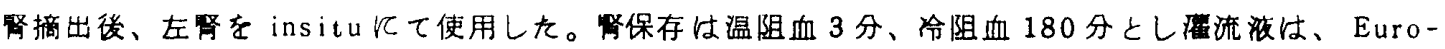

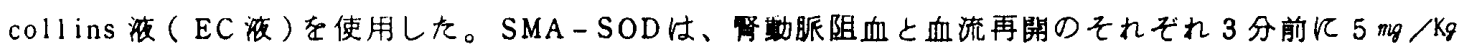

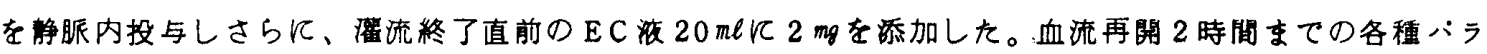
メータ一の絓時的測定を行った。

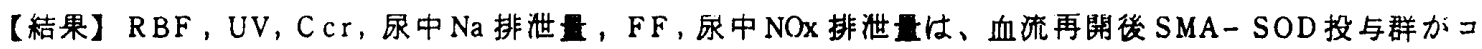
ントロール群に比して有意に增加した。

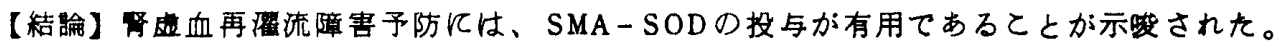

